\title{
АНТРОПОЛОГІЧНО-ЦІННІСНЕ ОСМИСЛЕННЯ ФЕНОМЕНУ СУБОТИ В КОНТЕКСТІ ФОРМУВАННЯ МЕТОДОЛОГІЇ І МЕТОДИКИ РОЗВИТКУ ЗДОРОВ'ЯЗБЕРЕЖУВАЛЬНОЇ КОМПЕТЕНТНОСТІ ВЧИТЕЛЯ ФІЗИЧНОЇ КУЛЬТУРИ В УМОВАХ ПІСЛЯДИПЛОМНОЇ ОСВІТИ
}

\begin{abstract}
У статті розкривається проблематика антропологічно-иіннісного осмислення культурно-духовних феноменів Суботи, Неділі і П'ятниці, щуо спрямовано на розробку методологї та методики розвитку здоров'язбережувальної компетентності вчителя фізичної культури в умовах післядипломної освіти, а також на удосконалення освітніх практик збереження здоров'я. Репрезентуються концепти станів

духовно-темпоральної і духовно-темпорально-локомоторної трансиенденціі. Визначаються шляхи використання уявлень про культурні традииї Суботи, Неділі і П'ятниџі для удосконалення професійних візій вчителя і його иіннісних орієнтацій, а також для розвитку міжкультурної комунікації, декомунізації освіти, методик організації рухової активності, збереження здоров'я і профілактики девіантної поведінки та хімічних залежностей.
\end{abstract}

Ключові слова: здоров'язбережувальна компетентність вчителя фізичної культури, Субота, Неділя, П'ятниия, післядипломна освіта, методологія, методика, педагогіка здоров'я, декомунізація, темпоральність, трансиендентність, духовність.

\author{
Сьомий день - це палац в часі. \\ Абрахам-Дюношуа Хешель \\ Qui habet tempus, habet vivat. \\ (В кого с час, в того с життя (лат.))
}

Постановка проблеми. Актуальність використання антропологічної парадигми, ціннісних, духовних та культурологічних візій для конструювання методології і методики розвитку здоров'язбережувальної компетентності вчителя фізичної культури в умовах неперервної освіти визначається демократичними і гуманістичними спрямуваннями української освіти, а також іiі кордоцентричними інтенціями. Це відповідає ідеям і смислам сучасних реформувань української освіти, в основі яких лежить концепція "Нової української школи" та європоцентричні соціокультурні трансформації. Тому особливо важливими в даному плані $є$ відродження національних традицій та розкриття Духу народу і нації в освітньому дискурсі, в рамках якого здоров'я має розглядатися не тільки як тілесний, але і як духовний, темпоральний, культурний і антропологічний феномени.

Дане культурологічне і духовне спрямування освіти не $є$ тільки національно орієнтованим, а націлене на актуалізацію всіх культурних традицій, в переважній більшості яких існують універсальні темпорально-антропологічні феномени Суботи, Неділі чи П'ятниці (в мусульман). Важливим $\epsilon$ співвідносне і інтегративне культурне і духовне відродження традицій всіх народів які населяють Україну, що може бути реалізоване також з використанням фізичної культури як Культури, а не тільки як технології рухової активності і збереження тілесного здоров’я.

Тому в контексті формування антропокультурного виміру педагогіки здоров'я ми говоримо також про актуалізацію аспекту інтернаціоналізації української освіти та розвиток міжкультурної комунікації. В цьому плані особливо цінним є повернення і реконструкція значимих аспектів традиційних культур, в яких проблематика часу та його структурування і осмислення є важливою та інтегрованою в життя, в здоров'язбережувальні і духовні практики. Ми актуалізуємо необхідність формування освітніх практик і технологій збереження здоров'я та відповідної компетентності на основі інтегративного використання антропологічного, культурологічного, темпорального, трансдисциплінарного i феноменологічного підходів, а також врахування духовних традицій народів та ідей інтернаціоналізації, гуманізації і європеїзації освіти.

Вказані методологічно-світоглядні інтенції визначають необхідність рецепції і включення як в методологічну систему, так і в методики і практики культурних традицій, принципів і візій. Таким чином, при розробці методології нашої педагогічної системи, як системоорганізуючий і визначальний аспект, нами представляється освітня та здоров'язбережувальна значимість української культурної та релігійної традицій, а також їх антропологічно і гуманістично орієнтованих інтерпретацій. Не менш значимою є використання і ціннісно-смислове осмислення духовних і темпоральних аспектів інших культур. В цьому плані первинною є актуалізація культурних і духовних візій Суботи, яка $є$ однією 3 
центральних в традиції іудаїзму. Таким чином, значимою складовою нашої проблематизації є питання міжкультурної комунікації і взаємодії, діалогу культур, дружби народів та культурного обміну.

Зазначені вище аспекти проблематизації, включаючи міжкультурну комунікацію, є методологічносвітоглядною та ідеологічною основою постановки питання про необхідність активного використання для розвитку здоров'язбережувальної компетентності вчителя фізичної культури, культурного, антропологічного і духовного вимірів культур. Важливим $\epsilon$ те, що і культура і буття можуть бути структурованими на часові, просторові, тілесні, аксіологічні та інші складові. Питання часу за своєю значимістю співвідноситься з проблематикою буття. Час є складовою індивідуального буття - часовою онтологією, цінністю і екзистенціалом темпоральності. Час є також одним з системоорганізуючих і центральних феноменів в культурі. Тому кожна культура виробляє свою специфіку його структурування. Уявлення про час в рамках традиційних культур має виразний відтінок гетерогенності, унікальності, зв’язку з життям і сакральним. Не дарма в українській культурі існують вислови "добра" чи "лиха" година та ін., які характеризують час, перш за все, якісно, антропологічно-ціннісно і духовно.

В сучасній українській освітній традиції, яка несе "секулярну печать" епохи модерну та комунізму, час переважно осмислюється в рамках лінійних, а не феноменологічних і онтологічних уявлень про нього. Тобто час як фон. Такий підхід, що $є$ характерним для суспільств модерну, базується на світоглядних інтенціях позитивізму, є основою "лінійного" тайм-менеджменту, в смислових рамках якого час структурується на період занять, години, робочі дні тощо. Тут домінує його кількісна, економічна і фізична характеристики.

Особливого значення в культурно визначеному структуруванні часу набуває феномен Суботи, глибинні смисли, якої обумовлені релігійними уявленнями про час як прояв сакрального. Зрозуміло, що в світській освітній традиції таке розуміння часу є відсутнім, та певною мірою, на жаль не припустимим. Це визначає технологічне відношення до часу як до середовища, як до аналога простору [1], як до декартівського res extenza (протяжності). Переважно час розуміється як ресурс, який потрібно берегти. Це "вершина" позитивіського, біологізаторського, технологічного і комерційного його розуміння.

В епоху модерну цілеспрямовано проводилася десемантизація і знецінення традиційних уявлень про час, і перш за все, про унікальність та святість Суботи і Неділі. Для цього свідомо комуністами організовувалися суботники і недільники. Символом цього було "нове" структурування часу, в якому відсутніми $\epsilon$ ідеї і інтенції сімейного спілкування, самозаглиблення, спокою, рівноваги, гармонії, осмислення свого і вищого буття. В замін "видавалися" - убогий колективізм та наївна, "вічна" i безтолкова боротьба "За это...", символом, якої було "Дайош", "Вперьод" та "Ленін 3 колодою" на суботнику. Символізм і реальность "Труда", "Війни", інфернального (нижнього), коллективного, транспарентного (прозорого в розумінні контрольованого) протиставлялися семантиці сакрального, гармонійного, врівноваженого, мирного, вищого, індивідуального, таємного, духовного. Нова радянська влада проводила руйнування культури шляхом акультурації 3 використанням маніпулювання темпоральними феноменами. Недарма програмна стаття лідера більшовиків В. Леніна "Від руйнування вікового укладу до творчості нового" безпосередньо містить виклик культурі, а також ії способу організації життя та "автентичному" часу культури - "віковому укладові". Людина мала віддати свій час і душу "молоху світлого майбутнього". Активно проводилася часова дезонтологізація, що відповідним чином було відображено і в освітніх практиках. Подібні процеси за їх модерніською і технологічною сутністю темпоральної дезонтологізації проходили і в західній традиції, але в делікатній і гуманній формі. Час там знецінювався через інтерпретацію його як гроші чи ресурс. В такому випадку час присвячувався Золотому тільцю, швидкості, досягненням.

Освітньо орієнтована проблематика феномену Суботи є актуальною в плані розуміння процесу збереження здоров'я як культурного i духовного феномену, як шляху осмислення цінностей, себе $\mathrm{i}$ способів організації буття. Тобто ми акцентуємо увагу на тому, що проблема, в якій час репрезентується як антропологічний i сакральний феномен Суботи, $є$ в освіті однією 3 базисних, світоглядних $\mathrm{i}$ методологічно значимих. В даному контексті значимим $є$ те, що здоров'язбережувальна практика вчителя фізичної культури, яка реалізується в рамках професійної діяльності, має виразний часовий аспект тому, що рухова активність за своєю природою темпоральна. Тобто вчитель фізичної культури "працює" $з$ часом, "проявленим" в руховій активності. В аспекті занять фізичною культурою і спортом феномен Суботи особливо $€$ цікавими в контексті рекреації та відновлення організму після навантаження.

В науковій педагогічній літературі питання використання культурно визначеної феноменології часу та феноменів Суботи і Неділі для формування методології та методики розвитку здоров'язбережувальної компетентності вчителя фізичної культури в умовах післядипломної освіти, а також співвідносного застосування в освітніх практиках збереження здоров'я висвітлено недостатньо. Це, разом із значущістю вище представлених аспектів збереження духовного, психологічного і тілесного здоров'я, визначає наше дослідження як актуальне.

Аналіз останніх досліджень і публікацій. Проблематика використання уявлень про культурно визначені феномени Суботи, Неділі і П'ятниці (залежно від культурної і релігійної традиції), а також 
співвідносні питання часу та темпоральності для формування методології і методики розвитку здоров'язбережувальної компетентності вчителя фізичної культури у світській педагогічній традиції розкрита не достатньо. На це вказує недостатня кількість робіт з даної тематики. Безумовно, що в релігійних освітніх i виховних практиках дані феномени, безпосередньо чи опосередковано, використовуються. Але вони, перш за все, є включеними у загальний контекст зазначених духовних традицій. При аналізі духовних і темпоральних питань виховні і творчі аспекти Суботи висвітлюють Ж. Дюкан, Ісраель-Меір Лау [2], Абрахам-Джошуа Хешель [1]. Проблематика темпоральної педагогіки, в рамках якої розглядаються феномени Суботи, Неділі i П’ятниці, розробляється В. Федорцем. Опосередковано i контекстуально педагогічно орієнтовані питання часу та природи дитини $\epsilon$ актуалізованими в рамках феноменологічної і екзистенційної педагогіки та педагогічної антропології, що в певній мірі відображено в роботах М. Шелера (M. Scheler), М. Бубера (M. Buber), О. Больнова (O. Bollnow), К. Роджерса (C. Rogers), А. Маслоу (А. Maslow), М. Лангевельда (M. Langeveld), Т. Бікмана (T. Beekman), Х. Бекрома (H. Bleeker), В. Лоха (W. Loch), К. Молленхауера (K. Mollenhauer), Д. Ванденберга (D. Vandenberg), Ф. Бойтендайка (F. Buytendijk), M. Манена (M. Van Manen), В. Ліппітца (W. Lippitz). Г. Кнеллера (G. Kneller), В. Морриса (W. Morris), Р. Харпера (R. Harper), Р. Штайнера (R. Steiner), Й. Дерболава (I. Derdolav), К. Ясперса (К. Jaspers) та ін.

Метою нашого дослідження була методологічно-світоглядна i антропологічно-ціннісна рефлексія уявлень про культурно-духовні традиції Суботи, Неділі і П'ятниці. Методологічно-світоглядне осмислення культурно-духовних феноменів Суботи, Неділі і П'ятниці спрямовувалося на розробку методології і методики розвитку здоров'язбережувальної компетентності вчителя фізичної культури в умовах неперервної освіти, а також для удосконалення освітніх практик збереження здоров'я (перш за все духовного і психологічного) та розвитку інтелекту, цінностей, гармонійної особистості, міжкультурної комунікації і декомунізації.

Виклад основного матеріалу. В світлі ідей феноменологічної педагогіки освіта $\epsilon$ інституціолізованим шляхом розкриття і реалізації смислу людського буття. Значимим виміром людського буття $є$ часове, яке, як зазначалося вище, має свої культурні і ціннісні репрезентації. Відповідно до вказаних бачень в нашій методологічній системі, ми розглядаємо проблематику буття i, перш за все, темпорального, як центральну та смислоформувальну.

Освітній процес за способом своєї організації переважно визначається не як темпоральнофеноменологічна, а як схематична і лінійно-часова структура. Організація часового буття в освітніх закладах, що включає розробку певних занять, рухових дій і тренувальних режимів, представляється у форматі "лінійного" тайм-менеджменту, що включає розподіл часу на навчальну і трудову діяльність та відпочинок. Осмислення часової природи освітнього процесу і темпоральності людини проводиться в рамках прийнятої парадигми діяльнісного підходу. Це визначає розуміння часу як фону для діяльності, в якій традиційно виділяють активність і відпочинок

Але ще з давніх часів в рамках культурно-релігійних традицій іудаїзму сформувалися значно ширші, якісно інші та вищі духовні та феноменологічно-антропологічні розуміння часу. Це розуміння часу як Суботи, що є для людини Темпоральним Храмом [1], захистом, Духовною онтологією і цінністю. Ще 3 часів античності іудейська традиція структурування часу на сім днів тижня з виділенням в ньому Суботи як особливого часу духовних пошуків була рецептована більшістю культур. Разом 3 тим, в здоров'язбережувальній педагогічній теорії і практиці уявлення про Суботу як особливий час розкриття духовної онтології людини не є достатньо актуалізованим. Тому ми оглядово розглянемо відомості про Суботу як духовний і темпоральний феномен в традиціях іудаїзму, Західного і Східного християнства, протестантизму, ісламу, а також представимо деякі аспекти актуалізації цієї духовної онтології в рамках нашої методологічної системи.

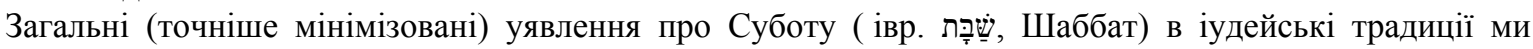
представимо (обмежуючи по можливості власні коментарі) на основі духовних знань розкритих равином i філософом Абрахамом-Джошуа Хешелем [1] в його творі "Шабат та його значення для сучасної людини" та равином Ісраель-Меір Лау в книзі "Практика іудаїзму в світлі усной Тори" [2]. Субота в іудаїзмі є одним з центральних духовних вчень і одкровень. Субота є "пам'яттю про справу Творення" [2], вказуючи на творчий акт Бога. Господь після творення світу установив особливий день: "Бо шість днів творив Господь небо та землю, море та все, що в них, і спочив Він в день сьомий - тому благословив Господь день сьомий і освятив його" [2]. Відповідно, якщо в Суботу ми не проводимо активної трудової, навчальної чи тренувальної діяльності, то це є співвідносним до дій Вищої Сили. I таким чином ми не протирічимо і не робимо виклику Господу.

Наступним аспектом Суботи є їі розуміння як "пам'яті про вихід з Єгипту" [2] і договір з Господом. Тому Субота є "найважливішою національною цінністю" [2] євреїв. Як пише Равин Ісраель-Меір Лау [2], Субота є переходом від темноти до світла, від буднів до святості, від рабства до свободи. Субота є дивом.

Актуальним виміром Суботи є загальна рівність [2]. Це розкрито в десяти заповідях - acepem xa-

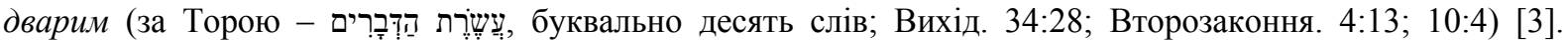


Дотримання, пам'ять і оберігання Суботи є четвертою заповіддю. Господь говорить: "Дотримуйся день суботній, щоб святити його, як заповідав тобі Яхве, Бог твій. Шість днів працюй і роби кожну справу свою, а день сьомий субота для Яхве, Бога твого: не роби нічого спільного, ні ти, ні син твій, ні дочка твоя, ні раб твій, ні рабиня твоя, ні віл твій, ні осел твій, ні всяка худоба твоя, ні прибулець в селищах твої, щоб відпочив раб твій і рабиня твоя, як ти. І пам'ятай, що ти був рабом у землі Сгипетській, але Яхве, Бог твій, вивів тебе звідти рукою дужою і долонею простягнутою; тому і наказав тобі Яхве, Бог твій, відправляти (дотримуватися) день суботній (Второзаконня 5: 12-15) [3]. Перебуваючи в Суботу в спілкуванні в колі сім’і, в молитві і в неактивній діяльності, люди різних статусів та можливостей стають рівними перед Богом. Равин Ісраель-Меір Лау говорить, що "В суботу немає працівника і роботодавця усі рівні перед Всевишнім" [2].

Субота розглядається як день Духу [2]. Вона освячує всі інші дні тижня [2]. В цей день вивчають святі книги і спрямовують свій погляд до духовного. Люди в Суботу спрямовують свою душу, тіло і думки від матеріальних занять на духовні пошуки.

В Суботу "Всі разом" [2]. Це стосується, перш за все, сімейного кола і близьких людей. В цей день $є$ можливість переключитися від маси різних проблем на своїх близьких та зрозуміти їх і себе [2]. Це день сім’ї як духовного способу організації буття. Як пише Равин Ісраель-Меір Лау, "Ось тут, біля суботнього столу - справжнє місце розвитку культури бесіди. Тут вчаться слухати і чути, говорити і розповідати, поглиблювати старе і відкривати нове" [2].

"Бережи і пам'ятай" Суботу [2]. "Пам’ятай Суботу" означає особливу підготовку і проведення її - в стані духовного, піднесення, з проведенням особливих ритуалів і читання суботніх молитов [2]. Існує

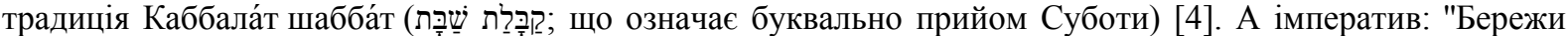
Суботу" регламентує відмову в цей день від певних видів занять, які спрямовані не на духовну сторону буття $[1 ; 2]$. Як вказує Равин Ісраель-Меір Лау: "...слід уникати того, що суперечить Духу Суботи - Духу Святого Дня" [2]. Важливими в збережені Суботи є особливі суботні духовні практики та підтримання "Духу Суботи" [2].

Активне заняття спортом чи фізичною культурою відносяться до занять, які не рекомендують проводити в Суботу. Вказані заняття не є духовними практиками і суперечать Духу Суботи та можливості людини заглибитися в себе і духовний вимір. Точніше, в цих заняттях є духовність, але досить специфічна - не високого і не Божественного порядку. Відповідно існує поняття спортивний дух, який є проявом специфічної "спортивної духовності".

Разом з тим Субота і не є відпочинком, як деякі вважають. Як говорить равин Абрахамом-Джошуа Хешель "Шаббат існує заради самого життя" [1]. Він також вказує на те, що "Шаббат - це найцінніший подарунок, отриманий людством зі скарбниці Бога" [1].

В традиції Західного християнства Субота в значній мірі трансформувалася у святкування Неділі [5: 146-147]. Але Східна християнська традиція відноситься до Суботи як до великого свята. Про це говорить професор богослов'я Андрій В'ячеславович Кураєв: "...Субота в православній пам'яті, в православному Богослужінні і богослові до цього часу святковий день" [6]. В протестантизмі культ суботи є актуальним у конфесії адвентистів сьомого дня [6].

В ісламі субота вважається днем відпочинку. А головним і духовним днем є П'ятниця [7: 253-255].

Таким чином на основі аналізу духовно-темпоральних, релігійних і культурних аспектів феноменів Суботи, Неділі і П’ятниці (в рамках різних культурно-релігійних традицій) ми можемо представити основні особливості структурування часу, на основі осмислення яких можливе удосконалення методології і методики розвитку здоров'язбережувальної компетентності. До вказаних особливостей ми відносимо: гетерогенне уявлення про час (час як нерівномірний феномен); виділення особливого часу, в якому розкривається і розгортається його та людська духовна сутність; структурування часу здійснюється в рамках біблійного космогонічного міфу; взаємозв'язок антропологічних аспектів часу і сакральних; актуальним є структурування на відносно великі проміжки - день, ніч, ранок, вечір тиждень; наявність регламентацій і відповідних табуювань діяльності в певні дні; розуміння часу як особливого діалогу людини з Богом, сім'єю, собою; час як спосіб виходу за свої межі - трансценденція; час як гармонізуючий чинник; час як рівність всіх перед Богом; зв'язок 3 певними духовними практиками (молитви, налаштування); переживання часу в рамках міфу про повернення; циклічність часу; субстанціонування часу і розуміння його як прояву Духу; аксіологічне і морально-етичне уявлення про час; зв'язок часу з людським буттям і трудовою діяльністю та активністю; зв'язок часу і духовного та психологічного здоров'я; темпорально орієнтоване виділення конкурентних видів діяльності фізичної та трудової активності і духовних занять (час як поле конкуренції); наскрізність і міжкультурний характер особливої, ціннісної і духовної темпоральності (Суботи, П'ятниці, Неділі); певного часу як способу організації буття та шляху духовного очищення і можливості оновлення себе; часу як особливої осмисленої і рефлексивної ментальної практики; часу як способу культурної адаптації і реалізації себе в історичному процесі. Але разом з тим виділені нами антропологічно-цінннісні узагальнення не відображають повноту і глибину духовної сутності Суботи, яка є якісно іншою та вищою. 
Продовжуючи аналізувати особливості структурування часу 3 метою осмислення духовної i темпоральної онтології Суботи 3 наукових позицій ми звертаємося до інтегративних напрямів хронобіології і хрономедицини [8: 5-24, 102-167, 230-239, 388-428]. В візіях цих наук людина $\epsilon$ надскладною системою біоритмів, які задаються антропною природою і синхронізуються та взаємодіють 3 середовищем (сонцем, планетами, Землею). Тобто темпоральна природа людини гетерогенна, нелінійна, циклічна, біоритмічна, зв'язана з всесвітом.

Людина має також свій внутрішній (іманентний) час. Едмунд Гуссерль вводить поняття "свідомості часу" (Zeitbewusstsein) [10], приділяючи особливу увагу темпоральному чиннику в організації і консолідації буття людини. Смке, величне і духовно-ціннісне розуміння часу розкриває нам равин Абрахам-Джошуа Гешель - "Час має незалежне первинне значення; в ньому більше величі, ніж навіть в зоряному небі, воно глибше вражає, вселяє більш сильне почуття благоговіння... Час - це процес творення, а речі в просторі - результат творення" [1]. Мартін Хайдеггер формує свою філософську доктрину на основі осмислення феноменології часу. Іманентний час не $є$ лінійним і не $\epsilon$ фоном, він $\epsilon$ способом розкриття буття і самим буттям - темпоральністю. Тому необхідно в освітніх практиках збереження здоров'я враховувати нелінійну, творчу, іманентну, екзистенцій ну, глибинну, "живу" i духовну природу часу.

Перейдемо до розгляду основних аспектів методологічно-ціннісної та методичної рефлексї культурно-релігійних феноменів Суботи, Неділі і П'ятниці. Аналіз даної проблематики ми проводимо на основі трандисциплінарного підходу та сформованих засновником екзистенційної педагогіки філософом і педагогом Отто Фрідріхом Больновим (нім. Otto Friedrich Bollnow, 1903-1991) феноменологічно орієнтовних методологічних принципів: "Антропологічної редукції" та "Антропологічної інтерпретації окремих феноменів".

Методологічно-світоглядний аспект культурно-релігійної автентичності і унікальності. Первинним при осмисленні культурних традицій Суботи [1; 2; 6], Неділі [5: 146-147; 6] та П'ятниці [7: 253-255] має бути розуміння, що вони не можуть бути повністю рецептовані і перенесені на життєві уклади чи безпосередньо на освітні практики. Ці традиції є проявом Духу. А Дух і духовні практики "не переноситься" і не технологізуються. Дух в кожної людини і в кожного народу має свої прояви. Тому не коректно і не потрібно копіювати чи ще "змішувати" інші традиції. Ми можемо поверхнево 3 ними знайомитися. В традиціях християнства, іудаїзму чи ісламу необхідно знаходитися з дитинства та бути в них посвяченим. Кожна релігійна традиція містить, як необхідну складову, таємницю і систему табу, які iii консолідують. Разом 3 тим певне і поверхневе знайомство 3 основними культурно-релігійними феноменами $\epsilon$ необхідною умовою для міжкультурної комунікації, миру, розвитку особистісного потенціалу та духовного і психологічного здоров’я. Незнання в даному аспекті породжує підозрілість і міфи. Можливими також можуть бути "поверхневі" запозичення.

Аспект необхідності врахування традицій Суботи. У зазначених традиціях Суботи $[1 ; 2 ; 6]$, Неділі [5: 146-147; 6] та П'ятниці [7: 253-255] інтегративно і цілісно відображені культурно та духовно визначені особливості структурування часу, уклади життя та взаємовідносини з сакральним. Це, 3 урахуванням духовної специфіки даного питання, вказує на можливість і необхідність коректного використання загальних і поверхневих уявлень вказаних традицій в освітній теорії і практиці збереження здоров'я. Історичність і поширеність, а також виразні світські аспекти культурно-духовних феноменів Суботи, Неділі, П’ятниці визначають необхідність урахування їх в розробці освітньої проблематики збереження здоров'я, що включає розвиток здоров'язбережувальної компетентності вчителя фізичної культури. Зазвичай світська педагогіка значною мірою ігнорувала ці традиції, які $€$ одними 3 центральних і конституюючих в культурах.

Необхідно відмітити, що людина є істотою спрямованою (інтенціональною) і здатною виходити за свої межі - трансцендентною. Тому в неї має бути час і день трансценденції. Значимим є коли інтенціональність людини буде спрямована до Вищих сил, а не до інфернальних (нижніх, пекельних). Тому, ми поруч із традиційними уявленнями про природно і соціокультурно визначені способи буття і психологічні стани людини, до яких відноситься діяльність (трудова, рухова, інтелектуальна), відпочинок, сон, трансові стани, пропонуємо виділити стан духовно-темпоральної трансценденції. Щодо рухової активності, то ми цей стан інтерпретуємо як духовно-темпорально-локомоторну трансценденцію, основою якої є символічні і цільові дії, які реалізуються в певному контексті і віці. Наприклад, похід людини до храму - це "не просто" рух. Він має інший і вищий смисл трансцендентний. На основі казаних візій ми формуємо концепт темпорально-трансиендентного (споглядального) niдxодy, який спрямований на розвиток і розкриття в дитини іiі потенцій (інтелекту, комунікативності, та ін.), автентичності, ідентичності, екзистенції шляхом актуалізації темпоральності. Цей підхід певною мірою "врівноважує" і гармонізує "активну життєву позицію", яка формується діяльнісним. Темпорально-трансцендентний (споглядальний) підхід має інтернальне (внутрішнє) спрямування на душу людини, на неї саму, на ії внутрішнє буття, а метою діяльніснісного є вплив на зовнішній світ. 
Відповідно до нашої гіпотези здатність і можливість до розкриття і прояву стану духовнотемпоральної трансценденції $\epsilon$ вродженою (i спадковою), інстинктивною і атрибутивною характеристикою людини. В дитинстві цей стан пов'язаний з руховою активністю, яка $є$ провідною в дитини, тому він $є$ духовно-темпорально-локомоторною трансценденцією. Уточнюючи відмітимо, що цей стан не $є$ відпочинком, хоча і даний аспект в ньому може бути присутній як вторинний. Проявляється стан духовно-темпоральної трансценденції первинно через осмислення часу та розкривається через специфіку культури, духовні і сімейні традиції. Але цей стан не обмежується тільки певним днем. Він може тривати хвилини і години чи дні. Основою розкриття стану духовнотемпоральної трансценденції є виключення "конкурентних" видів активної діяльності (роботи, спорту, фізичної культури та ін.). В даному контексті цікавою $є$ духовно спрямовані освітні реформи в Казахстані, в рамках яких включений новий предмет "Самопізнання" [9].

Аспект міжкультурної комунікащії. Врахування культурно-релігійних традицій Суботи $[1 ; 2 ; 6]$, Неділі [5: 146-147; 6] та П'ятниці [7: 253-255] є значимим аспектом при плануванні в навчальних закладах оздоровчих, спортивних, та інших заходів. Вказані заходи некоректно організовувати саме у ці дні. Це виклик культурам - акультурація. Результатом акультурації є девіантна і кримінальна поведінка, формування хімічних залежностей та інші особистісні і соціальні проблеми. Якщо зазначені заходи проводяться в Суботу, Неділю чи П'ятницю, то вони таким чином суперечать і знецінюють як релігійні, так і світські традиції християнства (Субота, Неділя), іудаїзму (Субота), ісламу (П'ятниця). Школа, як і фізична культура, має бути співвідносною $\mathrm{i}$ коеволюційною до культури, а також сприяти максимальному розкриттю культурного потенціалу учасників освітнього процесу.

Вказані нами візії і підходи також спрямовуються на використання особливих днів тижня для розвитку міжкультурної комунікації, дружби між народами та соціальної стабільності. Навіщо робити глибокий міжкультурний, релігійний і екзистенційно-темпоральний конфлікт тільки тому, що це зручно для педагогічного колективу чи так сказали "зверху"?!

Аспект декомунізащіi. Керуючись ідеологією та духом закону "Про засудження комуністичного та націонал-соціалістичного (нацистського) тоталітарних режимів в Україні та заборону пропаганди їхньої символіки" від 21 травня (опублікований 20 травня) 2015 року та враховуючи приховану антидуховну і дегуманізуючу традицію суботників та недільників, коли сама брудна і важка робота призначалася на дні усталених духовних практик, які формувалися тисячоліттями, вважаємо за доцільне рекомендувати не використовувати в освітньому процесі вказані комуністичні способи організації праці. Суботники - це знецінення духовного виміру буття, виклик Вищій силі, спосіб психологічного травмування дітей та закладка в них примітивного колективізму, нігілізму, агресії та системне отуплення. Особливо не доцільним і шкідливим є поєднання суботників з оздоровчими і спортивними заходами. Для вчителя фізичної культури це є актуальним тому, що в освітньому процесі він $є$ одним 3 тих, хто активно бере участь у більшості заходів.

Методичний аспект. Осмислюючи біблійний міф про творення, в якому виділений унікальний $\mathrm{i}$ особливий духовний статус Суботи, ми вважаємо за доцільне розуміти та інтерпретувати будь-які феномени і онтології, включаючи антропологічні та освітні, як такі, в яких є наявним духовний i темпоральний аспекти Суботи (Неділі, П'ятниці). Без Суботи цей світ був би неповним. I чи був би?!

Перейдемо до суто практичних аспектів. Розглянемо питання ціннісно-методичного і практично (технологічно) орієнтованого осмислення феноменів Суботи, Неділі, П’ятниці.

I. Формування ціннісних орієнтацій $i$ професійних візій вчителя. Субота в такому випадку розкривається і має бути наявною в серці педагога. Тому професійні візії і ціннісні орієнтації будуть включати розуміння дитини не тільки як об’єкту впливу, а як: прояв божественного, яке має свої унікальні і варіативні темпоральні шляхи розвитку; дитину, яка має свій час Суботи, що не $є$ відпочинком і не є активністю, а представляє шлях духовних пошуків і трансценденції; дитину як унікальний живий час; дитину як продовження і реалізацію акту божественного Творіння і прояв Духу. Сукупно вказані професійні візії є світоглядною і ціннісною передумовою освітніх практик, методик і способів впливу на учня, спрямованих на максимальне збереження його індивідуальних і темпоральноіндивідуальних особливостей, а не тотальну "переробку дитини" під замовлення домінуючої групи чи 3 власної ініціативи.

II. Актуалізація тижневого ритму тренувань $і$ відпочинку. Ми рекомендуємо в залежності від належності до релігійної конфесії чи культури один день у тиждень (Суботу, Неділю чи П'ятницю) не тренуватися взагалі. Якщо тренування все ж таки проводиться, воно має мати рекреаційний, "легкий", "розважальний" характер, а не цільовий і виснажливий. Таке обмеження не виключає рухову активність. Навпаки вона в цей день набуває символічних і духовних конотацій. Ідеєю вказаної рекомендації $\epsilon$ переключення зі сфер тілесності, рухової активності і діяльності на ментальну, символічну, ціннісну і духовну. Це підтверджується класичним вченням П. Анохіна про функціональні системи. Різні функціональні системи, завдяки яким реалізуються різноманітні види діяльності і буття, $\epsilon$ конкурентними між собою та такими, що витісняють одна одну. Наприклад, ми не можемо одночасно 
спати і їсти, чи активно займатися полюванням і проявляти любов до тварин та думати про вселенську доброту. Як вказує равин Абрахам-Джошуа Хешель: "Шість днів на тиждень ми прагнемо панувати над світом - в сьомий день ми намагаємося встановити панування над собою" [1]. І саме ця влада, яка йде від Духу, Часу і Серця, зупиняє людину перед нікчемною (в розумінні девіантною і кримінальною) поведінкою, перед вживанням наркотиків і алкоголю та цілим розмаїттям інших пригод і проблем.

III. Врахування феномену Суботи в організащії рухової активності. При плануванні занять і при розробці тренувальних режимів чи окремих рухових дій, ми рекомендуємо привносити в них аспект Суботи. Заняття має завершуватися практиками осмислення, діалогу, рефлексії. Тобто ми проводимо трансформацію тілесної і рухової активності в метальний, психологічний, духовний і темпоральний виміри. Формально - це інтенція "тіло - діалог (комунікація) - інтелект - духовна сфера". Частіше це використовується тренерами, які інтуїтивно розуміють, що завершити тренування необхідно через розкриття глибинних буттєвих питань, які можуть бути представлені у вигляді жарту, вільного спілкування тощо. Подібний прийом можна використати і на початку занять чи при навчанні складним руховим діям. Ми цей прийом, який розробляється нами в рамках феноменологічної і темпоральної педагогіки, називаємо темпоральним і діалогічно-темпоральним налаштуванням на рухову активність. Тут важливим $є$ також дух свободи, а не спроба дітей "гнати" на заняття, до вправи 3 радянським шикуваннями, ходінням строєм тощо.

Вказана практика спрямована також на витіснення небезпечних для життя i здоров'я модних технологій психогімнастики, яка переважно проводиться в кінці заняття. 3 позицій фізіології і медицини незрозуміло як після фізичного навантаження можна рекомендувати дитині прийняти горизонтальне положення і займалася самонавіюванням. Що буде з серцем в такому випадку?! Потрібно мінімум 10-20 (а реально 20-30) хвилин після фізичного навантаження коли ми це можемо робити. Але тоді, що залишиться від сорока п'яти хвилин заняття. При коловому тренуванні ми не рекомендуємо включати більше шести (може бути менше) вправ.

IV. Використання поваги до Ранку та виділення його як особливої часової онтології. В ранку також $\epsilon$ наявним духовно-темпоральний аспект Суботи. Тому для розкриття духовного, ціннісного i інтелектуального потенціалів ранку ми рекомендуємо наступне: прокидатися не в авральному чи військовому режимі ("щасливе" радянське "Падйом"); проводити ментально-ціннісні та діалогічні практики осмислення себе, сім’і, своїх справ чи інших актуальних для кожної особистості питань (думати, споглядати, медитувати, читати, творити, займатися мистецтвом, писати і спілкуватися); можуть бути також використані змішані ментально-локомоторні практики та прогулянки (хода стимулює когнітивну функцію); при умові належності до певної релігійної чи містичної традиції використовувати практики молитви та інші духовні заняття. Ранкова зарядка має проводитися після цих духовних i ментальних практик. В іншому випадку буде конкуренція в системах "рух, тіло - розум", "рух, тіло дух", де без сумніву перемагає тіло. Звичайно, якщо ми хочемо отримати особистість, яка "боїться" чи "не любить" мислити, то потрібно робити все навпаки. Що в СРСР робилося цілеспрямовано. Не рекомендуємо тренуватися (включаючи ранкову зарядку) раніше як за 15-20 хвилин (краще 30-40) після сну. Вказані візії є співвідносними з даними фізіології. Організм після сну не є готовим до навантаження. Потрібно хоча б 10-15 хвили щоб кров перерозподілитися 3 депо - селезінки і печінки та адаптувалося праве серце. В нічний період у вказаних органах депонується до 30 \% крові.

Узагальнючи ми актуалізуємо питання про інтелектуалізацію, аксіологізацію, антропологізацію, гуманізацію, темпоралізацію і одухотворення освітніх рухових практик та фізичної культури загалом (включаючи здоров'язбережувальну компетентність) на основі антропологічно-ціннісної рефлексії уявлень про духовні традицій Суботи. Завершуючи розгляд даної проблеми ми згадуємо давню темпорально-ціннісну сентенцію - Tempus ager meus (Час - це поле, яке я обробляю) та духовнотемпоральну ідею висловлену равином і філософом Абрахамом-Джошуа Хешелем про те, що "Найвища мета духовного життя полягає не в накопиченні великих обсягів інформації, а в сприйнятті моментів святості" [1].

Висновки.

1. На основі методологічно-світоглядної і антропологічно-ціннісної рефлексії культурно-духовних феноменів Суботи, Неділі і П'ятниці представлені шляхи використання деяких аспектів вказаних культурних явищ для розробки методології і методики розвитку здоров'язбережувальної компетентності вчителя фізичної культури та удосконалення освітніх практик збереження здоров'я.

2. Культурно-духовний феномен Суботи є унікальним та автентичним духовним надбанням іудейської релігійної і світської традицій. Осмислення феномену Суботи визначає розуміння буття, перш за все, в духовному, екзистенційному, феноменологічному, антропологічному, часовому, ціннісному і діалогічному вимірах. 3 методологічних позицій важливим $\epsilon$ те, що з сучасних філософських доктрин, в яких актуалізується проблематика часу, дотичними є концепції М. Хайдеггера, Е. Левінаса, А. Бергсона, К. Ясперса. Вказані філософські системи стали філософсько-методологічною основою феноменологічної і екзистенційної педагогіки. Разом з тим, духовна і темпоральна феноменологія Суботи і Неділі у 
вказаних педагогічних напрямах актуалізована не достатньо, що визначає необхідність розробки нами напряму - темпоральної педагогіки.

3. Врахування і актуалізація уявлень про феномени Суботи, Неділі і П’ятниці є складовою освітніх інтенцій декомунізації, в смислових рамках яких пропонується "демонтаж" радянської традиції суботників і недільників як тоталітарних, дивакуватих, дегуманізуючих і антидуховних антропопрактик.

4. Актуалізація традицій Суботи, Неділі і П’ятниці співвідносно з сучасними медичними, фізіологічними і хронобіологічними уявленнями визначає нелінійне, біоритмічне, духовне і темпоральне розуміння людини, що нами інтерпретується як значима (центральна) складова методологічної і духовної основи сучасної педагогіки здоров'я.

5. В культурно-духовному феномені Суботи відображені ідеї інтенціональності і трансцендентності людини як істоти духовної, темпоральної, моральної і розумної. На основі освітньоорієнтованої трансформації уявлень про Суботу і Неділю нами формуються концепти особливих станів відмінних від активної діяльності і відпочинку. Це концепти станів духовно-темпоральної $і$ духовно-темпоральнолокомоторної трансиенденції. Нами актуалізується необхідність використання в освітніх практиках збереження здоров'я концепту темпорально-трансиендентного (споглядального) підходу як такого, що врівноважує і гармонізує вплив діяльнісного.

6. Феномен Суботи в процесі історичного розвитку був використаний в релігійних системах християнства й ісламу. Тому духовну і темпоральну природу феноменів Суботи, Неділі та П'ятниці необхідно враховувати при організації освітнього процесу. Це є актуальним для розвитку міжкультурної комунікації, дружби між народами, миру, соціальної стабільності і для профілактики девіантної поведінки та хімічних залежностей.

7. Уявлення про культурно-духовний феномен Суботи пропонується застосувати для формування ціннісних орієнтацій та удосконалення професійних візій і інтенцій, вчителя, в рамках, яких дитина розглядається як особлива унікальна темпоральність в якій існує і розкривається акт Творення та прояв Духу. Це є світоглядно-ціннісною передумовою для формування здатності вчителя до коректного і делікатного ставлення до темпоральної і духовної унікальності та індивідуальності дитини.

Перспективи подальших досліджень. Ми надалі плануємо представити методичні аспекти даної проблематики, а також актуалізувати напрям міжкультурної комунікації.

\section{СПИСОК ВИКОРИСТАНИХ ДЖЕРЕЛ ТА ЛІТЕРАТУРИ}

1. Хешель А.-Д. Шаббат и его значение для современного человека / Абрахам-Джошуа Хешель. - Режим доступа : https://m.jeps.ru/Pdf/shabat.pdf (дата обращения : 01.07.18).

2. Лау Исраэль-Меир (раввин) Практика иудаизма : в свете устной Торы / Исраэль-Меир Лау. - Израиль : Модан, 1996. -460 c.

3. Десять заповедей // Электронная еврейская энцеклопедия. - Всемирный ОРТ. - Режим доступа : http://eleven.co.il/judaism/commandments-and-precepts/11412/ (дата обращения : 01.07.2018).

4. Суббота и праздники // Электронная еврейская энциклопедия / Всемирный ОРТ. - Режим доступа: http://eleven.co.il/judaism/sabbath-and-holidays/ (дата обращения: 01.07.2018).

5. Катехизис Католической Церкви : компендиум. - Москва : Духовная библиотека, 2007. - 217 с

6. Кураев А. Обращение к адвентистам / А. Кураев // Протестантам о Православии / диакон Андрей Кураев. Режим доступа : https://azbyka.ru/otechnik/sekty/protestantam-o-pravoslavii/10_(дата обращения : 01.07.2018).

7. Языджы С. Основы исламских знаний (вероучение, поклонение, нравственность) : пер. с тур. / С. Языджы. Изд. 6-е, стер. - Москва : Изд. группа САД, 2009. - 348 с.

8. Комаров О. М. Хронобиология и хрономедицина / О. М. Комаров, С. И. Рапопорт. - Москва : Триада-Х, $2000 .-488 \mathrm{c}$.

9. Абдрахманова Р. Б. Особенности и возможности предмета "Самопознание" / Р. Б. Абдрахманова. Елеуметтік педагог = Социальный педагог. - Павлодар, 2011. - № 1. - С. $42-44$.

10. Husserl E. Ideen zu einer reinen Phänomenologie und phänomenologischen Philosophie. Buch I. Husserliana III / E. Husserl. - Dordrecht : Kluwer Academic Publishers, 1977. - 195 s.

\section{REFERENCES (TRANSLATED \& TRANSLITERATED)}

1. Heschel Abraham-Joshua Shabbat i ego znachenie dlia sovremennogo cheloveka [Shabbat and Its Importance for Modern Man] / Abraham-Joshua Heschel. - Rezhym dostupu : https://m.jeps.ru/Pdf/shabat.pdf / (date of reference : 01.07.2018).

2. Lau Yisrael-Meir (Rabbi) Praktika iudaizma [Practical Judaism] : v svete ustnoi Tory / Yisrael-Meir Lau. - Izrail : Modan, 1996. -460 s.

3. Desiat zapovedei [Ten Commandments] // Elektronnaia evreiskaia entseklopediia [Electronic Jewish Encyclopedia]. - Vsemirnyi ORT. - Rezhym dostupu : http://eleven.co.il/judaism/commandments-and-precepts/11412/ (date of reference: 01.07.2018).

4. Subbota i prazdniki [Saturday and Holidays] // Elektronnaia evreyskaia entsiklopediia [Electronic Jewish Encyclopedia]. - Vsemirnyi ORT. - Rezhym dostupu : http://eleven.co.il/judaism/sabbath-and-holidays/ (date of reference : 01.07.2018). 
5. Katehizis Katolicheskoi Tserkvi [Catechism of the Catholic Church] : kompendium. - Moscow : Duhovnaia biblioteka, 2007. $-217 \mathrm{~s}$.

6. Kuraev A. Obraschenie k adventistam [Appeal to Adventists] / A. Kuraev // Protestantam o Pravoslavii [For Protestants about Orthodoxy] / diakon Andrei Kuraev. - Rezhym dostupu : https://azbyka.ru/otechnik/sekty/protestantam-o-pravoslavii/10 (date of reference : 01.07.2018).

7. Yazyidzhyi S. Osnovyi islamskikh znanii (verouchenie, poklonenie, nravstvennost) [Fundamentals of Islamic Knowledge (Dogma, Worship, Morality)] : per. s tur. / S. Yazyidzhyi. - Izd. 6-e, ster. - Moscow : Izd. gruppa SAD, 2009. $-348 \mathrm{~s}$.

8. Komarov O. M. Hronobiologiia i hronomeditsina [Chronobiology and Chronomedicine] / O. M. Komarov, S. I. Rapoport. - Moscow : Triada-H, 2000. - 488 s.

9. Abdrahmanova R. B. Osobennosti i vozmozhnosti predmeta "Samopoznanie" [Features and Capabilities of the Subject "Self-Knowledge"] / R. B. Abdrahmanova, V. A. Plehanova. - Áleýmettik pedagog=Sotsialnyi pedagog. Pavlodar, 2011. - № 1. - C. 42-44.

10. Husserl E. Ideen zu einer reinen Phänomenologie und phänomenologischen Philosophie. Buch I. Husserliana III / E. Husserl. - Dordrecht : Kluwer Academic Publishers, 1977. - 195 s.

\section{Федорец В. Н. Антропологически-ценносное осмысление феномена Субботы в контексте формирования методологии и методики развития здоровьесохраняющей компетентности учителя физической культуры в условиях последипломного образования.}

В статье раскрывается проблематика антропологически-иенностного осмысления культурно-духовных феноменов Субботы, Воскресенья и Пятницы, которое направлено на разработку методологии и методики развития здоровьесохраняющей компетентности учителя физической культурь в условиях последипломного образования, а также на совершенствование образовательных практик сохранения здоровья. Представляются кониепты состояний духовно-темпоральной и духовно-темпоральнолокомоторной трансиенденции. Определяются пути использования представлений о культурных традищиях Субботы, Воскресенья и Пятнищы для развития профессиональных визий учителя, межкультурной коммуникации, декоммунизации образования, методик организации двигательной активности, сохранения здоровья и профилактики девиантного поведения и химических зависимостей.

Ключевые слова: здоровьсохраняюшая компетентность учителя физической культуры, Суббота, Воскресенье, Пятница, последипломное образование, методология, методика, педагогика здоровья, декоммунизаџия, темпоральность, трансиендентность, духовность.

\section{Fedorets V. M. Anthropological and Value Apprehension of the Phenomenon of Saturday in the Context of Forming a Methodology and Methods of Development of the Health Preserving Competence of a Physical} Education Teacher in Conditions of Post-Graduate Education.

The article touches upon the issue of anthropological and value apprehension of the cultural-spiritual phenomena of Saturday, Sunday and Friday, which is aimed at the formation of the methodology and methods of development of the health preserving competence of a Physical Education teacher in conditions of post-graduate education as well as at the improvement of the existing educational practices of health conservation. Ideas of intentionality and transcendence of a person as a determined, spiritual and intelligent being are reflected in the spiritual and cultural phenomenon of Saturday. On the basis of apprehension of the cultural-spiritual phenomenon of Saturday, we represent the concepts of special states, which differ from energy demanding activities and active rest. These are the concepts of spiritual-temporal and spiritual-temporal-locomotor transcendence. The article determines the ways of using the existing ideas about the cultural traditions of Saturday, Sunday and Friday for the development of cross-cultural communication, methods of organizing locomotors activities, health preservation and prevention of deviant behavior and chemical dependencies.

Actualization of ideas about the phenomenon of a Saturday is a component of educational intentions of decommunisation within the framework of which it is planned to "destroy" the Soviet tradition of Saturday and Sunday voluntary work days for their being totalitarian, dehumanizing and anti-spiritual practices. Actualization of the traditions of Saturday, Sunday and Friday in correlation with current medical, physiological, chronobiological visions determines the spiritual, non-linear and temporal apprehension of person, which we interpret as a component of the methodological and spiritual basis of the contemporary pedagogy of health. We suggest

applying the ideas about the cultural and spiritual phenomenon of a Saturday to the formation of value orientations and improvement of professional visions and intentions of a teacher, within the framework of which a child is viewed as a unique temporality, in which the act of Creation and manifestation of Spirit are taking place.

Key words: health preserving competence of a Physical Education teacher, Saturday, Sunday, Friday, postgraduate education, methodology, methods, pedagogy of health, decommunisation, temporality, transcendence, spirituality. 